\title{
Comparison heat and mass transfer coefficients in the shell side of the hollow fiber membrane module
}

\author{
Sebastian Englart ${ }^{1, *}$ \\ ${ }^{1}$ Wrocław University of Science and Technology, Faculty of Environmental Engineering, Department \\ of Air Conditioning, Heating, Gas Engineering and Air Protection, 4/6 Norwida st., 50-373 Wrocław, \\ Poland
}

\begin{abstract}
The article discusses the theory associated with the determination of total heat and mass transfer coefficients in a membrane module. The equations for determining Nusselt and Sherwood numbers on the shell side of the module are presented. The design of the membrane module and the test bench are also discussed. The convective coefficients of heat and mass transfer on the shell side have been determined on the basis of the measurements. Calculation results obtained from correlation equations were then compared with the results of experimental investigations of convective heat and mass transfer coefficients in the airwater system. The equation is indicated appropriate for use in the case analysed.
\end{abstract}

\section{Introduction}

Membranes are currently used in many industries to conduct various types of separation processes. They can also be used in HVAC (heating, ventilation and air conditioning) systems to conduct air treatment processes for example drying, humidifying or evaporative cooling [1-3]. The benefits of using membranes in the air treatment process include, for example, lack of direct contact between liquid and air, elimination of liquid droplets in the air stream, prevention of microorganisms, bacteria or spores between phases and prevention of liquid contamination by airborne dust $[4,5]$. Such benefits are not offered by traditional air treatment techniques.

A problematic issue may be the design of large-scale membrane modules due to the discrepancies associated with the determination of heat and mass transfer coefficients. An accurate prediction of the efficiency of the hollow fibre membrane can be limited by models of heat and mass transfer coefficient on the shell side. Several correlation equations have been developed by various authors for the different processes and conditions of fluid flow through the membrane module, allowing the determination of the $N u$ and $S h$ numbers on the shell side $[6,7]$. The application of certain equations may result in large discrepancies in the results of calculations.

\footnotetext{
* Corresponding author: sebastian.englart@pwr.edu.pl
} 
This article hence presents examples of empirical equations for determining $\mathrm{Nu}$ and $\mathrm{Sh}$ numbers. The results of the calculations obtained from correlation equations were compared with the results of experimental investigations of convective heat and mass transfer coefficients in the air-water system. The equations appropriate for use in the analysed case were then indicated.

\section{Theory}

As a membrane module, the calculation of the heat and mass exchanger requires, among others, determination of hydrodynamic conditions of the flow of individual fluid streams and determination of heat and mass transfer coefficients as well as determination of the average temperature or concentration difference. The basic equations used in the design of exchangers are equations that allow us to determine the total heat and mass flows. According to studies $[8,9]$ the overall mass transfer rate can be determined as:

$$
N=K_{o l} A \Delta C_{l n}
$$

Analogously for the heat transfer rate:

$$
Q=H_{o l} A \Delta T_{l n}
$$

\subsection{Overall heat and mass transfer coefficients}

The overall heat and mass transfer coefficients may then be determined while accounting for the individual resistances. For the mass transfer coefficient, Mahmud et al. [10] and Nii et al. [11] indicate that resistance on the water side can be omitted. Therefore, the overall mass transfer coefficient from water to air can be obtained from the following equation:

$$
K_{o l}=\frac{1}{R_{k m}+R_{k a}}
$$

Similarly, one can determine the heat transfer coefficient $[4,12,13]$ :

$$
H_{o l}=\frac{1}{R_{h m}+R_{h a}}
$$

Resistances in equations (3) and (4) can be determined using the formulas given by Zhang [12]:

$$
\begin{aligned}
& R_{k m}=\frac{\delta}{D_{v m}}\left(\frac{d_{o}}{d_{i}}\right) \text { and } R_{k a}=\frac{1}{k_{o}} \\
& R_{h m}=\frac{\delta}{\lambda_{m}}\left(\frac{d_{o}}{d_{i}}\right) \text { and } R_{h a}=\frac{1}{h_{o}}
\end{aligned}
$$

The amount of heat and mass exchanged by the air in the whole membrane module per unit of time is given the following equations: 


$$
\begin{aligned}
& Q=m_{a} c_{p a}\left(t_{1}-t_{2}\right) \\
& N=m_{a}\left(x_{2}-x_{1}\right)
\end{aligned}
$$

Experimentally, taking into account equations (1-2) and (7-8), the overall heat and mass transfer coefficients can be calculated as:

$$
\begin{gathered}
H_{o l}=\frac{m_{a} c_{p a}\left(t_{1}-t_{2}\right)}{A \Delta T_{l n}} \\
K_{o l}=\frac{m_{a}\left(x_{2}-x_{1}\right)}{A \Delta C_{l n}}
\end{gathered}
$$

In the case of the membrane module, when the water circulates in a closed circuit as a result of heat and mass exchange processes, the water temperature is set $\left(t_{w l}=t_{w 2}\right)$, hence:

$$
\Delta T_{\ln }=\frac{\left(t_{a 1}-t_{a 2}\right)}{\ln \left(\frac{t_{a 1}-t_{w 1}}{t_{a 2}-t_{w 1}}\right)}
$$

Analogously, the logarithmic mean difference of concentrations can be determined as [14]:

$$
\Delta C_{l n}=\frac{\left(C_{a 2}-C_{a 1}\right)}{\ln \left(\frac{C_{w 1}-C_{a 1}}{C_{w 1}-C_{a 2}}\right)}=\frac{\left(x_{a 2} \rho_{a 2}-x_{a 1} \rho_{a 1}\right)}{\ln \left(\frac{x_{a t_{w 1}} \rho_{a t_{w 1}}-x_{a 1} \rho_{a 1}}{x_{a t_{w 1}} \rho_{a t_{w 1}}-x_{a 2} \rho_{a 2}}\right)}
$$

\subsection{Shell side heat and mass transfer coefficient}

The convective coefficients of heat and mass transfer on the shell side will depend on the geometry of the module, the system of membranes in the module, or the method of fluid flow through the module. These coefficients can be expressed respectively by Nusselt and Sherwood number:

$$
N u=\frac{h_{o} d_{o}}{\lambda_{a}}, S h=\frac{k_{o} d_{o}}{D}
$$

Correlation equations allowing to determine $N u$ and $S h$ numbers on the shell side of the membrane module are summarised in Table 1 and Table 2. $N u$ and $S h$ number can also be determined by way of the analogy to heat and mass transfer [15]:

$$
\frac{N u}{P r^{1 / 3}}=\frac{S h}{S c^{1 / 3}}
$$


Table 1. Correlations of Nusselt numbers for fluid flow across tube bank (staggered arrangement).

\begin{tabular}{|c|c|c|}
\hline $\begin{array}{c}\text { Authors and } \\
\text { references }\end{array}$ & Correlations & No \\
\hline Colburn [16] & $N u=0.33 \operatorname{Re}^{0.6} \operatorname{Pr}^{1 / 3}$ & (15) \\
\hline $\begin{array}{c}\text { Chen and } \\
\text { Wung [17] }\end{array}$ & $N u=0.78 \operatorname{Re}^{0.45} \operatorname{Pr}^{0.38}$ & $(16)$ \\
\hline $\begin{array}{c}\text { Zukauskas } \\
{[18]}\end{array}$ & $N u=C \operatorname{Re}^{n} \operatorname{Pr}^{0.36}\left(\operatorname{Pr} / \operatorname{Pr}_{S}\right)^{1 / 4}$ & (17) \\
\hline $\mathrm{C}$ and n are given in [15] & (18) \\
\hline Hausen [19] & $N u=0.35 F_{a} \operatorname{Re}^{0.57} \operatorname{Pr}^{0.31}$ & \\
\hline
\end{tabular}

Table 2. Shell side mass transfer correlations.

\begin{tabular}{|c|c|c|}
\hline $\begin{array}{c}\text { Authors and } \\
\text { references }\end{array}$ & Correlations & No \\
\hline $\begin{array}{l}\text { Cote et al. } \\
{[20]}\end{array}$ & $S h=0.61 R e^{0.363} S c^{0.33}$ & (19) \\
\hline $\begin{array}{c}\text { Yang and } \\
\text { Cussler [21] }\end{array}$ & $S h=1.38 R e^{0.34} S c^{0.33}$ & (20) \\
\hline $\begin{array}{l}\text { Kreith and } \\
\text { Black [22] }\end{array}$ & $S h=0.39 R e^{0.59} S c^{0.33}$ & (21) \\
\hline $\begin{array}{l}\text { Costello et } \\
\text { al. [23] }\end{array}$ & $S h=(0.53-0.58 \phi) R e^{0.53} S c^{0.33}$ & (22) \\
\hline $\begin{array}{l}\text { Gawroński } \\
\text { and } \\
\text { Wrzesińska } \\
{[24]}\end{array}$ & $S h=0.09(1-\phi) R e^{(0.8-0.16 \phi)} S c^{0.33}$ & (23) \\
\hline $\begin{array}{l}\text { Prasad and } \\
\text { Sirkar }[25]\end{array}$ & $S h=5.85(1-\phi)\left(\frac{d_{h}}{L}\right) R e^{0.6} S c^{0.33}$ & (24) \\
\hline $\begin{array}{c}\text { Koo and } \\
\text { Sangani }[26]\end{array}$ & $S h=1.89(0.42-0.90 \phi)(1-\phi)^{1 / 3}\left(\frac{d_{O}}{L}\right)^{1 / 3} R e^{1 / 3} S c^{1 / 3}$ & $(25)$ \\
\hline $\begin{array}{l}\text { Johnson et } \\
\text { al. [27] }\end{array}$ & $S h=0.24\left(\operatorname{Re} \frac{d_{h}}{L}\right)^{0.59} S c^{0.33}$ & (26) \\
\hline Zhang [28] & $\begin{array}{c}S h=\left(14.06 \phi^{4}-29.21 \phi^{3}+22.59 \phi^{2}-7.71 \phi+1.03\right) R e^{0.33} S c^{0.33} \psi_{k} \\
\psi_{k}=0.882 d_{f}-0.535\end{array}$ & (27) \\
\hline
\end{tabular}

The schematic drawing of the module and the way the membranes are arranged as shown in Figure 1. For heat exchangers with cross-flow, the Reynolds number should be determined at the maximum velocity [29]:

$$
\begin{gathered}
\operatorname{Re}=\frac{u_{a \max } d_{o}}{v_{a}}, u_{a \max }=\max \left[\left(\frac{b}{b-1}\right) u_{a},\left(\frac{b}{c-1}\right) u_{a}\right] \\
a=\frac{S_{L}}{d_{o}}, b=\frac{S_{T}}{d_{o}}, c=\sqrt{a^{2}+(b / 2)^{2}}
\end{gathered}
$$

where: 
If $S_{L}=S_{T}$, dimensionless coefficient $a$ for a staggered arrangement can be determined from the following equation [12]:

$$
a=\left(\frac{\pi}{2 \sqrt{3} \phi}\right)^{0.5}
$$

Experimentally, convective heat and mass transfer coefficient can be determined taking into account equations (3-6) and (9-10) as:

$$
h_{o}=\left(\frac{1}{\frac{m_{a} c_{p a}\left(t_{1}-t_{2}\right)}{A \Delta T_{l n}}}-R_{h m}\right)^{-1}, k_{o}=\left(\frac{1}{\frac{m_{a}\left(x_{2}-x_{1}\right)}{A \Delta C_{l n}}-R_{k m}}\right)^{-1}
$$

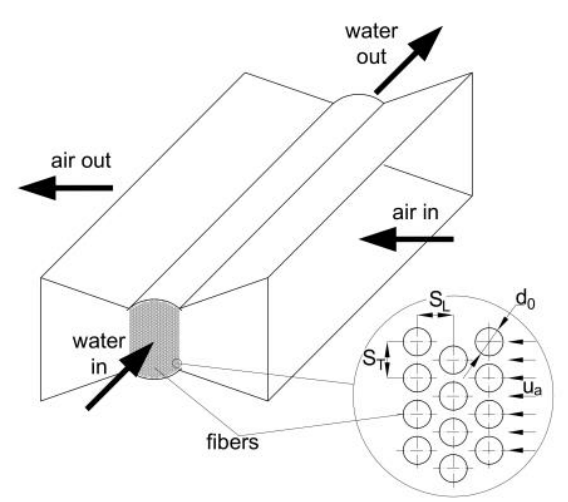

Fig. 1. Schematic of the membrane module and the arrangement of fiber bundles.

\section{Experimental setup}

To determine the experimental convective coefficients of heat and mass transfer on the air side, a membrane module with a polypropylene capillary membrane (PP) was used with the following parameters: $1.67 \mathrm{~mm}$ membrane inner diameter, $2.71 \mathrm{~mm}$ membrane outer diameter, $0.43 \mu \mathrm{m}$ average pore size and $0.55 \mu \mathrm{m}$ maximum pore size. The module uses 744 membranes. The effective length of the membranes, equal to the length of the air inlet, was $400 \mathrm{~mm}$, which gave an effective area of $2.53 \mathrm{~m}^{2}$. The packing density was $663 \mathrm{~m}^{2} / \mathrm{m}^{3}$, packing friction was 0.45 . The membranes were arranged perpendicular to the direction of the air flow (Fig. 1).

The measurements were carried out on the test bench, the diagram of which is shown in Figure 2. The test bench was equipped with devices enabling measurement of the following parameters: temperature and humidity of the outside air; temperature and humidity of the air at the inlet and outlet of the membrane module; air flow rate in the duct; water temperature before and behind the module, water flow rate.

The measurements were carried out for variable air and water flow. For air, the flow was changed in the range of $80-120 \mathrm{~m}^{3} / \mathrm{h}$ and for water: $40-100 \mathrm{~kg} / \mathrm{h}$. One example of air conversion in a test installation (in a membrane module) which takes into account the parameters of the outside air during measurements (point 1) is shown in the diagram i-x (Fig. 3). 

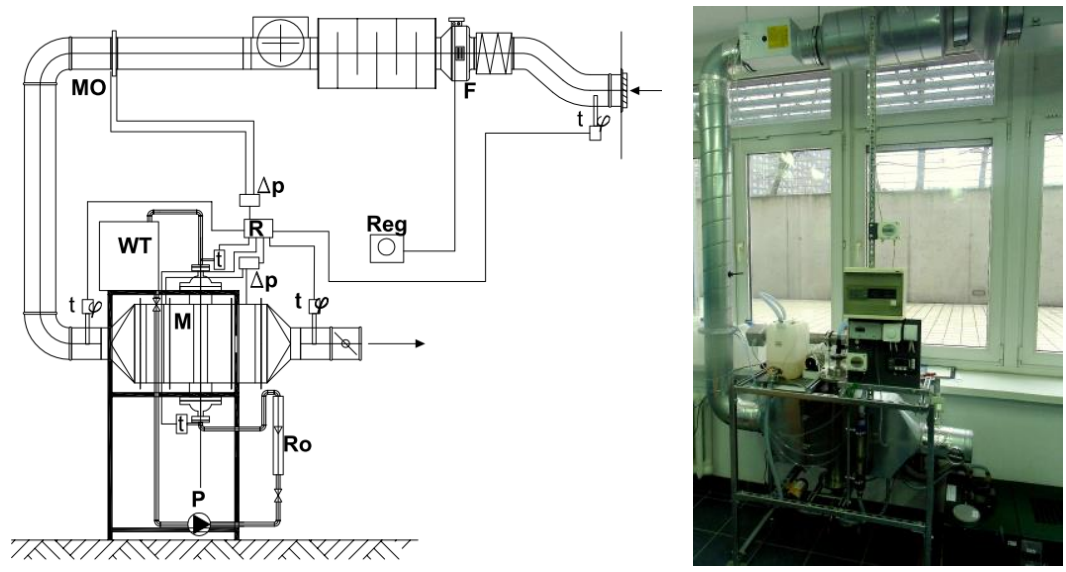

Fig. 2. Schematic diagram and view of the test bench. $\mathrm{F}$ - fan, $\mathrm{MO}$ - measuring orifice, $\mathrm{Ro}$ - rotameter, $\mathrm{R}$ - recorder, $\mathrm{WT}$ - water reservoir, $\mathrm{M}$ - membrane module, $\mathrm{P}$ - pump, Reg - thyristor controller, sensors of: $\mathrm{t}$ - temperature, $\varphi$ - humidity, $\Delta \mathrm{p}$ - differential pressure.

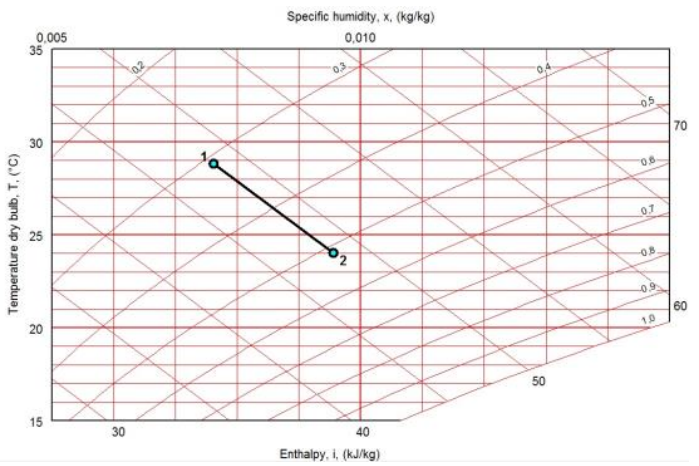

Fig. 3. An example of air conversion in the experimental installation for $m_{a}=112 \mathrm{~m}^{3} / \mathrm{h}$ and $m_{w}=40 \mathrm{~kg} / \mathrm{h}$.

\section{Results and discussion}

The experimental values of the Nusselt and Sherwood numbers were obtained by averaging results from experimental data determined at different water and air flows. The values obtained in this way were compared with the values obtained from existing correlations describing convective heat and mass transfer coefficients on the external side of the membrane module (according to Tables 1 and 2).

The results of the analysis are presented in diagrams in the form of the dependence of $N u=f(R e)$ and $S h=f(R e)$ (Fig. 4a and Fig. 4b). The analysis shows that $N u$ and $S h$ numbers are functions increasing with an increase in $R e$ number and virtually independent of the stream of water flowing through the membranes. The variation of $N u$ number ranged from 0.92 to 1.46 and in the case of $S h$ number it was from 0.78 to 1.59 .

Figure $4 \mathrm{a}$ shows that good fit between experimental and calculated data can be obtained after applying equation (14) for correlation (24) according to Prasad and Sirkar [25] and worse from equation (25) by Koo and Sangani [26]. The remaining equations significantly overstate the obtained results in relation to the experimental data. The membrane module is similar to a shell and tube heat exchanger. However, there are several differences between 
these systems, for example: membranes are flexible, fibers have a small diameter. As a result, the flow in the shell side has a much more complicated profile than that in heat exchangers. This may be the reason overstate $N u$ numbers obtained from equations (15)-(18). In the case of mass transfer, the experimental data could also be found between the results obtained from equations (24) and (25) (Fig. 4 b). Hence, not taking into account effect of module geometry, such as membrane packing fraction ratio, the equations typical for cross-flow have significantly overestimated the obtained values in relation to the experimental data obtained.
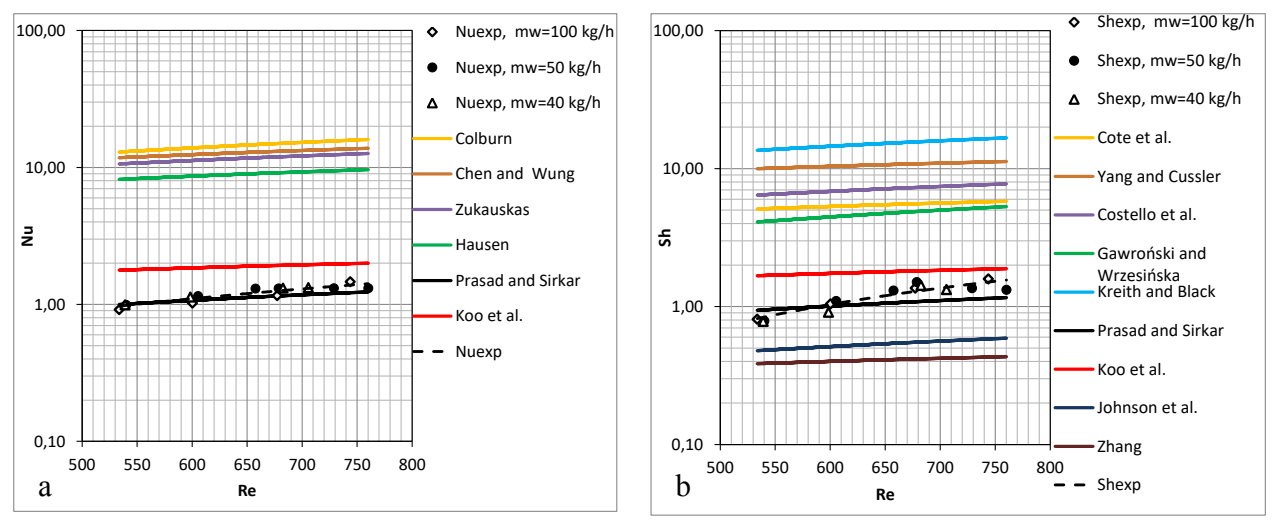

Fig. 4. Comparison of shell side heat (a) and mass (b) transfer between model predictions and observation in module.

\section{Conclusions}

Among the equations compared here describing the mass transfer on the shell side of the module, the best fit of experimental data was obtained from the equation (24) developed by Prasad and Sirkar [25]. The average difference between the experimental values of $S h$ numbers and the calculated from this equation was $17 \%$. After applying the equation describing the analogy between heat and mass transfer, equation (24) by Prasad and Sirkar can be used to determine the Nusselt number. In this case, the average difference between the experimental $N u$ numbers and the calculated did not exceed $8 \%$.

\section{Nomenclature}

$A-$ area $\left(\mathrm{m}^{2}\right)$

$b$ - dimensionless transverse pitch

$c$-dimensionless diagonal pitch

$d$-diameter $(\mathrm{m})$

$D_{v m}$ - effective moisture diffusivity $\left(\mathrm{m}^{2} \mathrm{~s}\right)$

$h_{o}$ - convective heat transfer $\left(\mathrm{W} /\left(\mathrm{m}^{2} \mathrm{~K}\right)\right)$

$k_{o}-$ convective heat transfer $(\mathrm{m} / \mathrm{s})$

$m$ - mass flow rate $(\mathrm{kg} / \mathrm{s})$

$Q$ - heat transfer rate (W)

$u_{a}-$ approach velocity $(\mathrm{m} / \mathrm{s})$

$x$ - moisture content $(\mathrm{kg} / \mathrm{kg})$

$\lambda$ - heat conductivity $(\mathrm{W} /(\mathrm{mK}))$

$\delta$ - membrane thickness (m) $a$-dimensionless longitudinal pitch

$C$ - concentration $\left(\mathrm{kg} / \mathrm{m}^{3}\right)$

$c_{p}-$ specific heat $(\mathrm{J} /(\mathrm{kgK}))$

$D$ - diffusivity $\left(\mathrm{m}^{2} \mathrm{~s}\right)$

$H_{o l}$ - overall heat transfer $\left(\mathrm{W} /\left(\mathrm{m}^{2} \mathrm{~K}\right)\right)$

$K_{o l}$ - overall mass transfer $(\mathrm{m} / \mathrm{s})$

$L$ - length of hollow fiber (m)

$N$ - mass transfer rate $\left(\mathrm{kg} / \mathrm{m}^{3}\right)$

$t$ - temperature $(\mathrm{K})$

$u_{\max }-$ maximum velocity $(\mathrm{m} / \mathrm{s})$

$\phi$-packing fraction

$v$ - kinematic viscosity $\left(\mathrm{m}^{2} / \mathrm{s}\right)$ 
Subscripts:

1 - inlet, 2 - outlet, $a$ - air, $d$ - dry bulb, $f$ - fractal, $h$ - hydraulic, $i$ - inner, $m$ - membrane, $o$ - outer, $w$ - water

The work was realized within the allocation No. 0401/0007/17 awarded for Faculty of Environmental Engineering Wroclaw University of Science and Technology by Ministry of Science and Higher Education in years 2017-2018.

\section{References}

1. S. Englart, E3S Web Conf. 17, 00021 (2017)

2. S. Englart, E3S Web Conf. 22, 00040 (2017)

3. J. Woods, Renew. Sust. Energ. Rev. 33, 290-304 (2014)

4. S. Bergero, A. Chiari, Appl. Therm. Eng. 21, 1119-1135 (2001)

5. D.W. Johnson, C. Yavuzturk, J. Pruis, J. Membr. Sci. 227, 159-171 (2003)

6. S. Shen, S.E. Kentish, G.W. Stevens, Solvent Extr. Ion Exc. 28, 817-844 (2010)

7. S.M. Huang, L.Z. Zhang, Renew. Sust. Energ. Rev. 28, 425-440 (2013)

8. K.R. Kistler, E.L. Cussler, Trans. IChemE, Part A 80, 53-64 (2002)

9. V.Y. Dinore, G.F Versteeg, Int. J. Heat and mass 48, 3352-3362 (2005)

10. H. Mahmud, A. Kumar, R.M. Narbaitz, T. Matsuura, J. Membr. Sci. 179, 29-41 (2000)

11. S. Nii, R.S. Jebson, E.L. Cussler, J. Membr. Sci. 201, 149-159 (2002)

12. L.Z. Zhang, Int. J. Heat. Mass. Tran. 55, 5861-5869 (2012)

13. N.T. Charles, D.W. Johnson, J. Membr. Sci. 319, 44-53 (2008)

14. A. Kmieć, S. Englart, A. Ludwińska, Theory and technique of fluidization (Publishing House of Wroclaw University of Technology, Wroclaw, 2007)

15. F.P. Incropera, D.P. DeWitt, T.L. Bergman, A.S. Lavine, Fundamentals of Heat and Mass Transfer (John Wiley \& Sons publishers Inc, New York, 2007)

16. A.P. Colburn, Trans. Am. Inst. Chem. Eng. 29, 174-210 (1933)

17. C.J. Chen, T.S. Wung, ASME J. Heat Transfer 111, 641-648 (1989)

18. A. Žukauskas, Advances in Heat Transfer 8, 93-160 (1972)

19. H. Hausen, Heat Transfer in Counterflow, Parallel Flow and Cross Flow (McGrawHill, New York, 1983)

20. P. Cote, J. Bersillon, A. Huyard, J. Membr. Sci. 47, 91-106 (1989)

21. M. Yang, E.L Cussler, AIChE J. 32, 11, 1910-1916 (1986)

22. F. Kreith, W.Z. Black, Basic Heat Transfer (Harper \& Row, New York, 1980)

23. M.J. Costello, A.G. Fane, P.A.Hogan, R.W. Schofield, J. Membr. Sci. 80, 1-11 (1993)

24. R. Gawroński, B. Wrzesińska, J. Membr. Sci. 168, 213-222 (2000)

25. R. Prasad, K.K. Sirkar, AIChE J. 34, 2, 177-188 (1988)

26. S. Koo, A.S. Sangani, J. Fluid. Mech. 484, 255-282 (2003)

27. D.W. Johnson, M.J.Semmens, J.S. Gulliver, J. Membr. Sci. 128, 67-81 (1997)

28. L.Z. Zhang, Int. J. Heat. Mass. Tran. 54, 2921-2931 (2011)

29. W.A. Khan, J.R. Culham, M.M. Yovanovich, J. Thermophys Heat Transfer 20, 720-727 (2006) 